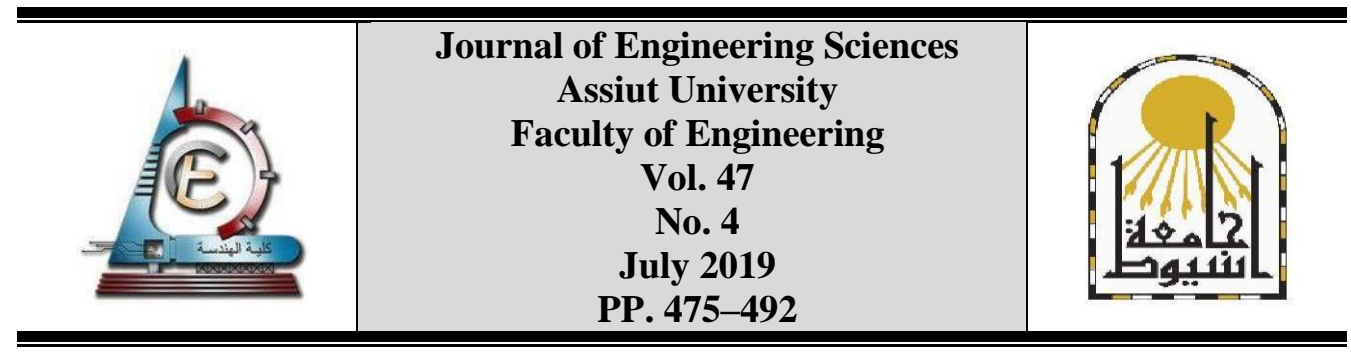

\title{
INFLUENCE OF INFLOW SEWAGE CHARACTERISTICS ON THE PERFORMANCE OF TAHTA WASTE STABILIZATION PONDS IN COMPARISON WITH THE DESIGN ONES
}

\author{
Gamal Abozeid ${ }^{1}$, Mohamed E. Eldardeer ${ }^{2}$ and Aya A. Elmohands ${ }^{3}$ \\ ${ }^{1,2}$ Civil Eng. Dept, Assiut University \\ ${ }^{3}$ M. Sc. Researcher
}

Received 11 April 2019; Accepted 11 May 2019

\begin{abstract}
TAHTA waste water treatment plant is a (WSPs) constructed for treatment the domestic waste water of TAHTA city which located at a latitude of $26^{\circ} 42^{\prime} \mathrm{N}$ and a longitude of $31^{\circ} 41^{\prime} \mathrm{E}$ and it is about $91.00 \mathrm{~m}$ above the sea level. The performance of TAHTA plant along the three years of study period is estimated in the form of a comparison between the results of the total system or its components with the allowable values of the studied parameters, or in a relation between the input and the output of these parameters as efficiency. The final effluent characteristics are compared with the designed ones and with those recommended by Egyptian Code of Practice $(\boldsymbol{E C P})$ and Food and Agriculture Organization $(\boldsymbol{F A O})$ for re-use of water treated by this type of treatment. The existing operation is considered as unrealistic because of the deviation of its input flow parameters from the designed ones. The plant ponds were designed for full capacity flow rates, recommended influent BOD, etc. So, this research aiming to: 1) Evaluate the performance of the plant under existing operation conditions. 2) Examine whether the treated water quality in the range of standards set by $(\boldsymbol{E C P})$ for this type of treatment. 3) Identify the problems associates with the plant. 4) Suggest ways to improve the performance of the treatment plant. The study is performed experimentally where the daily sampling and laboratory analysis were carried out according the standard specifications. The study revealed that 1) Plant system is working satisfactory in the period of study to fulfil the requirement of use its treated water in irrigating forest trees which is the one of its construction purposes. 2) As the performance of the plant did not meet the design one at the operation parameters such as low flow rate and low coming $\mathrm{BOD}_{5}$ loadings for treating some parameters due to sludge accumulation in anaerobic ponds, or because the incoming rate of sewage in 2016 is higher than the plant design capacity. So; $\boldsymbol{a})$ Sludge accumulated in anaerobic ponds should be removed when its depth reaches $1.00 \mathrm{~m}$ according the design recommendations or when it is one half full of the sludge by volume [13]. b) Flow distribution should be checked to be uniform otherwise a short circuiting problem is faced. $\boldsymbol{c}$ ) Inflow rate must be checked otherwise, to receive more of sewage inflow coming from the surround area than its design capacity some modifications may be used to improve (WSPs) efficiency. 3) According to $(\boldsymbol{E C P})$ and $(\boldsymbol{F A} \boldsymbol{O})$ recommendation, the treated wastewater from TAHTA plant is acceptable for re-used in the irrigation of wooden tree forests.
\end{abstract}

Keywords: Sewage Characteristics, Treatment, Stabilization Ponds, Performance, TAHTA Plant. 


\section{Introduction}

In Egypt nowadays, the treated wastewater is used in irrigating some specified corps becomes an urgent need. Sewage treatment is the process of eliminating pollutants from sewage water (Tchobanoglous \& Burton, 1991)[1]. Wastewater treatment plants construction aim to allow human and industrial effluents to be disposed of without danger to human health or unacceptable damage to the natural environment (Kamyotra \& Bhardwaj, 2011)[2]. Waste stabilization ponds (WSPs) are constructed for the purpose of the treatment of wastewater biologically by the help of natural processes including pond algae and bacteria. WSPs technology is considered as the most effective method for treating domestic as well as industrial effluent where ample land is available and the climate is benignant for their operation (Mara, 1976)[3]. Long Ho et al., 2018 [4], conducted a laboratory study on models for low cost-effective conventional activated sludge (AS) and low cost and easy operation, nature-based systems such as constructed wetlands (CWs) and (WSPs). They found that both natural systems showed moderate nutrient removal efficiencies and concluded that WSPs are recommended as a more attractive alternative for AS.

Because of the basic design data information is often not readily available in developing countries due to limited resources; traditional methods of process design for WSP are unreliable and resulting in either under-design or overdesign of the system, with implications for the costs of the project (Von Sperling, 1996)[5]. Physical, biological and chemical factors that influence the behavior of El-Qusiyyah plant were studied by $\mathbf{A z a b}$ 2016[6] in order to raise its performance. He conclude that according the $(\boldsymbol{E C P})$ the treated water produced from El-Qusiyyah ponds is valid for irrigation in both long and short term usage. Almasi et al. 2018 [7], performed an experimental study on the effect of solar light on coliform variations in facultative stabilization pond. They conclude that regarding the positive effect of temperature on the coliform death, use of facultative stabilization pond in a warm climate is suggested. Seif et al., 2018[8], formulated the mathematical model which was developed by Danish Hydraulic Institute (DHI) to simulate and apply WQ parameter on El-Burullus Lake. They concluded that waste ponds efficiency can be improved easily and economically by making baffles in the lake which can increase the water velocity, avoided the dead zones area and reduce the eutrophic concentration. Kumar et al., 2018[9] analyzed and discussed waste stabilization pond as a technical option for liquid waste management in rural areas in Haryana. They recommended that the Gram Panchayat should place solid waste system management before the implementation of liquid waste management projects for their effective management and sustainability.

For TAHTA WSPs, the existing working wastewater flow is significantly changed in comparison with those used in the design. Similarly, wastewater $\mathrm{BOD}_{5}$ varies as the per capita $\mathrm{BOD}_{5}$ changes when a community's level of income improves (Campos and Von Sperling, 1996)[10]. These uncertainties call into question about the reliability and the performance of the plant. This research seeks to compare the existing WSPs output parameters with those designed by traditional methods. Analysis of the results will show how the existing performance of TAHTA WSPs to comply with the recommended by $(\boldsymbol{E C P})$.

\section{Experimental work}

A recent full-scale of WSPs was completely constructed in TAHTA city, Sohage Governorate. Its operation started at the year of 2005. Figure (1) shows the general layout of the system. The plant serves both TAHTA city and some of the surrounding villages and 
designed to treat municipal wastewater. The total design volume of the plant $31906 \mathrm{~m}^{3} /$ day of wastewater, but the range of measured discharge was found to be from $14225.4 \mathrm{~m}^{3} /$ day to $35870 \mathrm{~m}^{3} /$ day over the three years of study. The plant consists of a collecting chamber (entrance) that receives raw wastewater. After the entrance, wastewater passes a bar screen, then it directs to the discharge measurement unit (weir). The recorded maximum flow rates were in 2016 due additional sewage from other surrounding villages which were higher than the designe flow rate of the plant.

After that, wastewater feeds six parallel series of ponds. Each series consists of $5.00 \mathrm{~m}$ deep anaerobic pond with 0.5625 ha surface area, facultative pond of $2 \mathrm{~m}$ deep and of 4.015 ha surface area, while the maturation pond has $1.5 \mathrm{~m}$ deep and 1.43 ha surface area. All ponds are lined with $10 \mathrm{~mm}$ thick plastic sheets covered by $100 \mathrm{~mm}$ plain concrete to prevent the groundwater contamination. Wastewater flows between ponds by gravity. The detention time of anaerobic, facultative and maturation ponds are 4.0, 15.0 and 4.0 days respectively. The collected samples were from five different locations in the plant. These locations were set with the design at the inlet of raw sewage, at outlet of each pond and at plant effluent. Column samples were taken and kept in two litres beaker glass. Each sample was directly fixed for laboratory analysis. A daily collection of samples were conducted through the experimental period from January 2014 to December 2016.

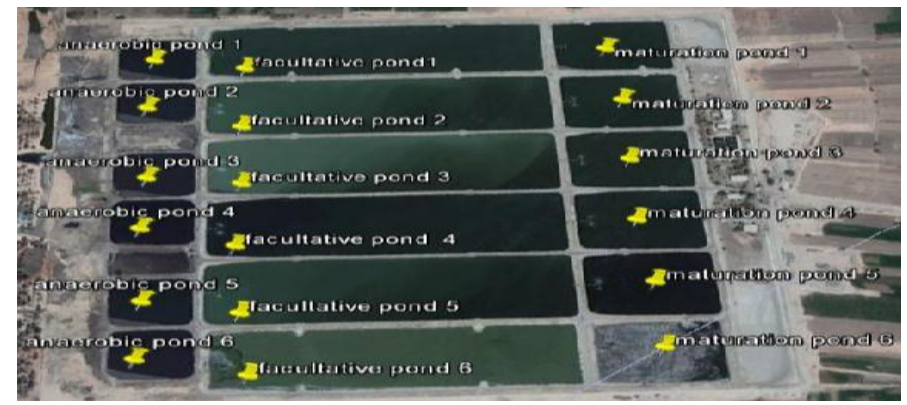

Fig. 1. TAHTA WSPs components.

For each sample, the measured parameters were; $\mathrm{T}, \mathrm{pH}, \mathrm{DO}, \mathrm{BOD}_{5}, \mathrm{TSS}$, TDS, ammonia, oil \& grease, phosphate, sulphide. All laboratory measurements were performed according to standard methods for the examination of water and wastewater (APHA, 2012)[11].

\section{Results and discussions}

The measured concentrations of the studied parameters of WSPs effluent define the grade of the treatment. (ECP, 2015)[12] and (FAO, 1992)[13] are correctly identify the limits of treated water concentrations for its re-use in agriculture. Performance evaluation of WSPs system may be discussed in a form of comparison between the results of the whole system or its components with the allowable values of the studied parameters, or in relation between the input and the output of these parameters as an efficiency of the total system or the efficiency of its components from the following form:

$$
\text { Efficiency }(\%)=\left|\frac{\left(P_{\text {in }}-P_{\text {eff }}\right)}{P_{\text {in }}}\right| \times 100
$$

where: $\mathrm{P}_{\text {in }}$ and $\mathrm{P}_{\text {eff }}$ are the influent and effluent waste materials concentrations, respectively. 
The analysis of the recorded data and results will be discussed in the following articles.

\section{Performance of TAHTA plant in the form of temperature}

Temperature is an uncontrolled factor and it has a great effect in the design equations and on the performance of WSPs. The efficiency of a properly designed WSPs increases with the increase of temperature. Mara and Pearson 1998 [14] argue that a properly designed anaerobic pond can achieve around $60 \%$ BOD removal at $20^{\circ} \mathrm{C}$ and over $70 \%$ at $25^{\circ} \mathrm{C}$. The monthly measured average-values of temperature over the year of 2014 are tabulated in Table (1) as an example. Yearly average wastewater temperatures of the influent, anaerobic, facultative, maturation ponds and those of the effluent were $25.69^{\circ} \mathrm{C}, 24.5^{\circ} \mathrm{C}, 23.56^{\circ} \mathrm{C}$, $22.9^{\circ} \mathrm{C}$, and $21.35^{\circ} \mathrm{C}$, respectively. With the evaporation effect from the water surface of the ponds, it is seen a gradually decreased of temperature of the wastewater from the influent to the effluent along the ponds series. The results are in agreement with the design one and with the recommended values by Mara and Pearson 1998 [14]

Figure (2) shows the effluent temperature measured over the three years 2014, 2015 and 2016. The measured average temperatures of the effluent are lower than that of treated domestic water recommended value $\left(35^{\circ} \mathrm{C}\right)$ by $(\boldsymbol{E C P}$, No. 501- 2015) [12], to be drained in surface water.

Table 1.

The temperatures measured along TAHTA series of ponds over the year of 2014 .

\begin{tabular}{|c|c|c|c|c|c|}
\hline Months & Influent & Anaerobic pond & $\begin{array}{c}\text { Facultative } \\
\text { pond }\end{array}$ & $\begin{array}{c}\text { Maturation } \\
\text { pond }\end{array}$ & Effluent \\
\hline Jan. & 20.025 & 18.4 & 17.4 & 17.5 & 17.40 \\
\hline Feb. & 20.9 & 18.3 & 17.8 & 17.7 & 18.30 \\
\hline March & 22.75 & 22.3 & 21.5 & 20.8 & 19.53 \\
\hline April & 23.57 & 24.5 & 23.9 & 23.2 & 20.18 \\
\hline May & 27.65 & 27.3 & 26.4 & 25.8 & 21.04 \\
\hline June & 28.892 & 27.2 & 26 & 25.3 & 24.75 \\
\hline July & 29.56 & 28.7 & 27.8 & 26.7 & 24.58 \\
\hline Aug. & 28.87 & 27.6 & 26.7 & 26.1 & 24.81 \\
\hline Sep. & 28.025 & 27.2 & 26.5 & 25.4 & 23.10 \\
\hline Oct. & 27.5 & 26.2 & 25.3 & 24.2 & 22.60 \\
\hline Nov. & 26.36 & 26.2 & 25.1 & 24.2 & 21.45 \\
\hline Dec. & 24.125 & 20.1 & 18.3 & 17.9 & 18.45 \\
\hline Range & $20.03-29.56$ & $18.3-28.7$ & $17.4-27.8$ & $17.5-26.7$ & $17.4-24.8$ \\
\hline
\end{tabular}

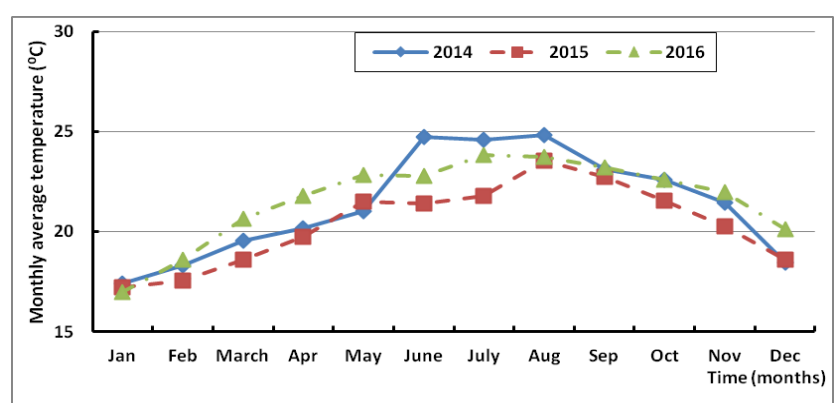

Fig. 2. Values of the temperatures of effluent water from TAHTA WSPs at the years 2014, 2015 and 2016. 


\section{Performance of TAHTA plant in the form of (PH)}

WSPs performance is dependent on $(\mathrm{pH})$ values of water in the ponds. Ammonia and sulphide toxicity have been observed to be $\mathrm{pH}$-dependent (Konig et al. 1987 [15]). As the $\mathrm{pH}$ of a facultative pond increases, the unionized form of ammonia increases while sulphide production decreases. The effect of this toxicity is to inhibit algae growth and production. A less amount of BOD removal occurs in maturation ponds due to their lower algal concentrations (Mara, 1997) [16]. The annual average-values of measured (pH) in the influent, anaerobic, facultative, maturation ponds and those of effluent were 6.8, 6.9, $7.3,7.5$ and 7.77, respectively. For example, the monthly measured average-values of $(\mathrm{pH})$ along the series of ponds through 2014 are shown as in Fig. (3). It is shown an increase in $\mathrm{pH}$ values occurred along the ponds. This increase may be relayed to the rapid photosynthesis by the ponds' algae, which consumes $\mathrm{CO}_{2}$ faster than it can be replaced by bacterial respiration; resulted in carbonate and bicarbonate ions dissociate. Algae fix the resulting $\mathrm{CO}_{2}$ from the dissociation while hydroxyl ions accumulate so raising the $\mathrm{pH}$ value, often above 9 . At $(\mathrm{pH}>9)$ faecal bacteria die very quickly and the photosynthesis activity of algae becomes less (Gad et al, 2005)[17].

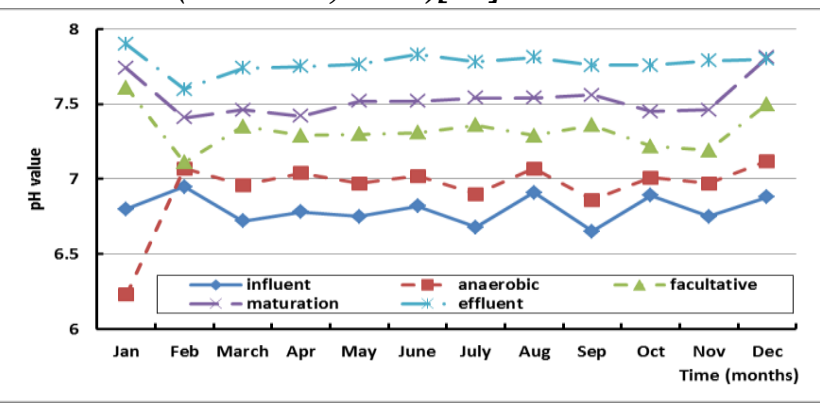

Fig 3. Variations of monthly wastewater $(\mathrm{pH})$ along TAHTA plant series of ponds measured at the year of 2014 .

Effluent $(\mathrm{pH})$ measured over the three years 2014, 2015 and 2016 and the allowable ones recommended by (ECP, No. 501- 2015) [12], are shown drawing in Fig. (4). The drawings show the effluent water from the ponds has a $\mathrm{pH}$ values range from 7.6 to 7.9 which is less than the recommended ones over the three years and this water is acceptable to irrigate wooden tree forsts [12 and 13]. It is noted from the figure the lower $\mathrm{pH}$ values are in the year of 2016. This may attributed to the incoming rate of sewage is higher than the plant design capacity.

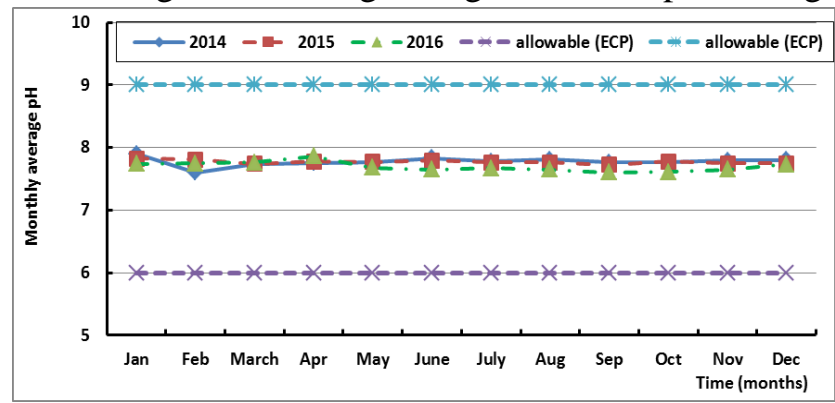

Fig. 4. Values of hydrogen power $(\mathrm{pH})$ measured for the effluent and the allowable ones for TAHTA WSPs at the years 2014, 2015 and 2016.

Equation (1) is used to calculate the monthly efficiency of $\mathrm{pH}$ increment from the influent and effluent measured wastewater total $(\mathrm{pH})$ over the years of 2014, 2015 and 2016. The 
calculated values of the efficiencies are shown drawn against the time (months) of the three years as in Fig. (5). It is seen the overall increment efficiency of $(\mathrm{pH})$ varied between $16.69 \%$ and $9.35 \%$ for 2014 and varied between $16.89 \%$ and $11.57 \%$ for 2015 while it is varied between $15.59 \%$ and $10.03 \%$ for 2016 . It is noted that the yearly average increment efficiency equals to $14.37 \%, 13.92 \%$ and $12.97 \%$ for 2014,2015 and 2016 , respectively.

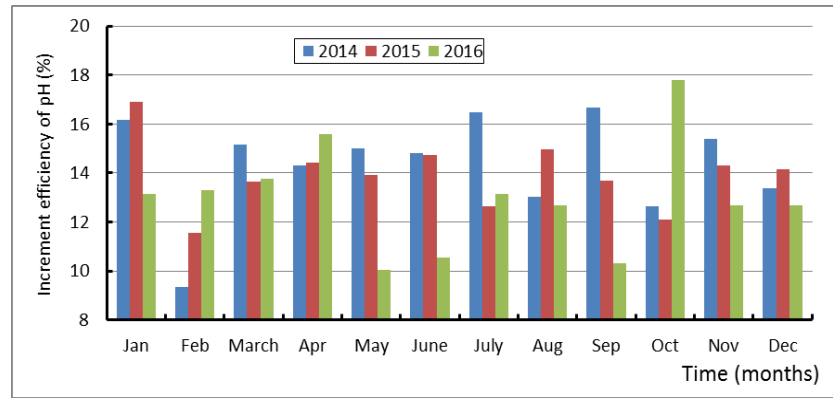

Fig 5. Variations of total monthly increment efficiency of $(\mathrm{pH})$ for TAHTA plant over the years of 2014, 2015 and 2016.

\section{Performance of TAHTA plant in the form of (DO) increament}

Dissolved oxygen (DO) is an important indicator for satisfactory operation of facultative and maturation ponds. It is seen from the monthly observations over the year of 2014 shown in Fig. (6), the measured concentration of (DO) in the facultative pond was ranged between 1.0 $\mathrm{mg} / \mathrm{L}$ and $2.1 \mathrm{mg} / \mathrm{L}$ and in maturation ponds it was enhanced to be in the range from $2.1 \mathrm{mg} / \mathrm{L}$ to $4.0 \mathrm{mg} / \mathrm{L}$. The (DO) increased in the effluent water to be from (4.09 to 5.04$) \mathrm{mg} / \mathrm{L}$. This increase of (DO) through the treatment series of WSPs may be attributed to the algal oxygen production, the occurring reduction of the biochemical oxygen demands $\left(\mathrm{BOD}_{5}\right)$ and the transformation of the oxygen from the air to wastewater through the surface of ponds.

$(\boldsymbol{E C P})$ and $(\boldsymbol{F A} \boldsymbol{O})$ recommend a (DO) level for treated water re-use in agriculture not to decrease than $4 \mathrm{mg} / \mathrm{L}$. It is seen from the data drawn in Fig. (7), the effluent of the ponds has a (DO) values range from 3.5 to $5 \mathrm{mg} / \mathrm{L}$. In comparison with the recommended values, the best values of DO were recorded in the year of 2014, while the worst ones were recorded in 2016. This may attributed to the incoming rate of sewage is higher than the design capacity of the plant and the coming water from anaerobic and facultative ponds has high concentration of $\left(\mathrm{BOD}_{5}\right)$ than the design one.

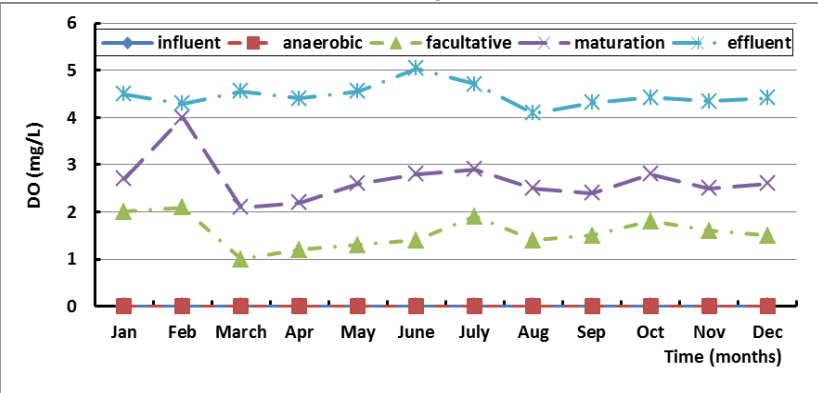

Fig. 6. Variations of wastewater dissolved oxygen (DO) along TAHTA plant series of ponds measured at the year of 2014 . 


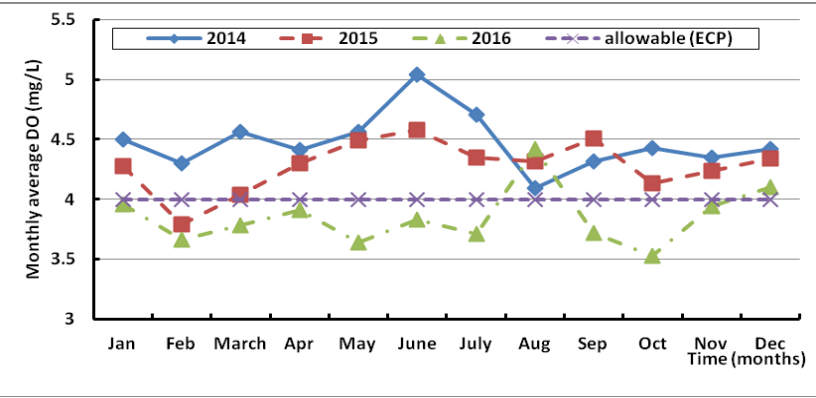

Fig. 7.Values of effluent dissolved oxygen (DO) and the allowable ones for TAHTA WSPs at the years 2014, 2015 and 2016.

\section{Performance of TAHTA plant in the form of (BOD5) removal}

$\mathrm{BOD}_{5}$ and pathogens removal are the primary goals of WSPs system, where anaerobic and facultative ponds are installed for $\mathrm{BOD}_{5}$ removal and maturation ponds are employed for tertiary treatment, i.e. to remove excreted pathogens and nutrients. The unfiltered $\mathrm{BOD}_{5}$ measured concentrations along the series of ponds over the year of 2014 are drawn as an example in Fig. (8). The recorded values of $\mathrm{BOD}_{5}$ of raw wastewater were ranged between $257.5 \mathrm{mg} / \mathrm{L}$ to $216.67 \mathrm{mg} / \mathrm{L}$, with an annual average value of $231.15 \mathrm{mg} / \mathrm{L}$. In the anaerobic, facultative, maturation ponds and the effluent, the yearly average concentration of the unfiltered $\mathrm{BOD}_{5}$ was reduced to be $162.5 \mathrm{mg} / \mathrm{L}, 114.17 \mathrm{mg} / \mathrm{L}, 90.0 \mathrm{mg} / \mathrm{L}$ and 45.42 $\mathrm{mg} / \mathrm{L}$, respectively. The effluent $\mathrm{BOD}_{5}$ concentration is slightly higher than the design one.

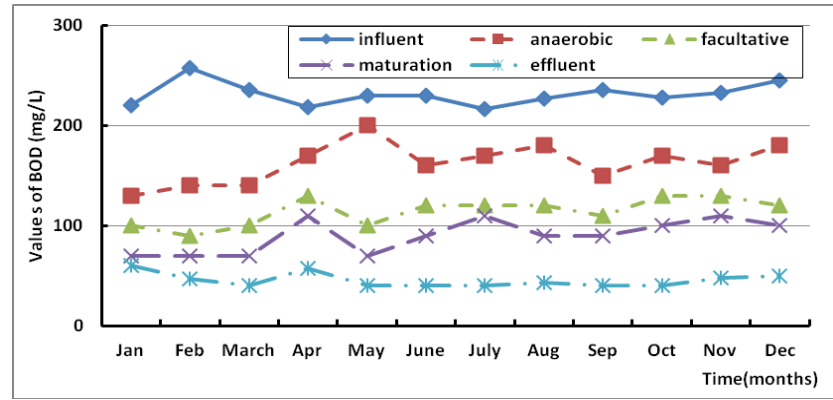

Fig. 8. Variations of wastewater $\left(\mathrm{BOD}_{5}\right)$ along TAHTA plant series of ponds measured at the year of 2014 .

The measured data of $\left(\mathrm{BOD}_{5}\right)$ over the three years of 2014, 2015 and 2016 for the effluent water from the plant are drawn as in Fig. (9). Design allowable values are appeared on the figure. Effluent of the ponds has $\left(\mathrm{BOD}_{5}\right)$ values range from 40 to $85 \mathrm{mg} / \mathrm{L}$. In comparison with the design allowable value, except for some months in 2014, all the recorded data over the period of study were higher than the design allowable one, but it is in consistent with the recommended values by $(\boldsymbol{E C P})$ and $(\boldsymbol{F A} \boldsymbol{O})$ for irrigating forest trees.

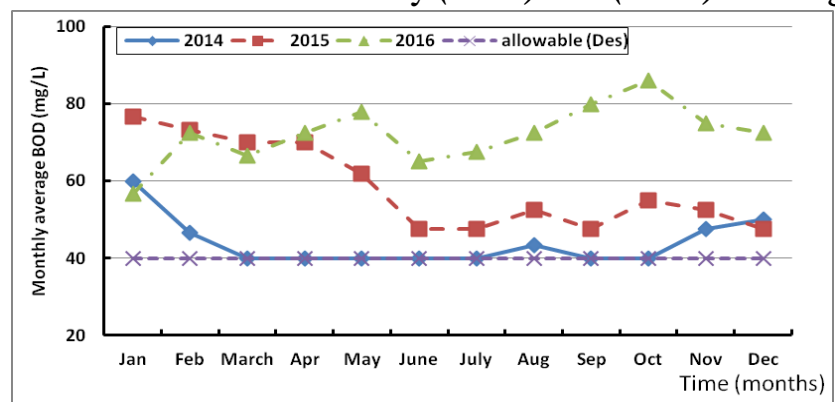

Fig. 9. Values of measured $\left(\mathrm{BOD}_{5}\right)$ and the design allowable ones of the effluent from TAHTA WSPs at the years 2014, 2015 and 2016. 
Variations of measured total removal efficiency of $\left(\mathrm{BOD}_{5}\right)$ for TAHTA plant are calculated according Eq. (1) from the influent and effluent measured wastewater biochemical oxygen demand $\left(\mathrm{BOD}_{5}\right)$ over the years of 2014, 2015 and 2016. The monthly calculated efficiencies for the three years are shown drawn as in Fig. (10). It is seen the overall removal efficiencies of $\mathrm{BOD}_{5}$ varied between $83.0 \%$ and $72.7 \%$ for 2014 and varied between $81.6 \%$ and $69.0 \%$ for 2015 while it is varied between $75.1 \%$ and $62.6 \%$ for 2016 . It is noted that yearly removal efficiencies equals to $80.28 \%, 76.71 \%$ and 68.41 for 2014 , 2015 and 2016, respectively. This is strong evidence that the plant is working well and the system total efficiency is higher than $50.65 \%$ which was found by (Ghazy et al. 2008) [18]. Also, it is seen a slightly increase in $\left(\mathrm{BOD}_{5}\right)$ removal efficiency in worm months.

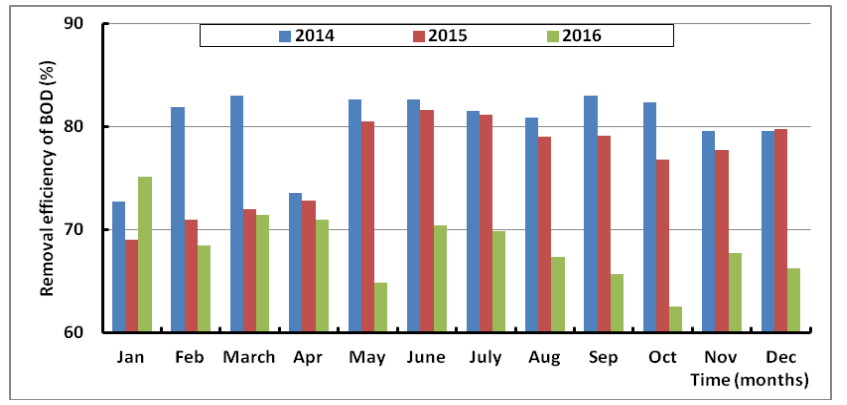

Fig 10. Variations of total removal efficiency of $\left(\mathrm{BOD}_{5}\right)$ for TAHTA plant over the years of 2014, 2015 and 2016.

\section{Performance of TAHTA plant in the form of (TSS) removal}

Total suspended solids (TSS) concentrations measured in the series of ponds over the year of 2014 are drawn for example as shown in Fig. (11). Annual-average measured concentration in the influent was $229.8 \mathrm{mg} / \mathrm{L}$. In the anaerobic, facultative, maturation ponds and the effluent, the yearly average concentrations of (TSS) were $138.4 \mathrm{mg} / \mathrm{L}, 107$ $\mathrm{mg} / \mathrm{L}$, and $85.4 \mathrm{mg} / \mathrm{L}$ and $41.2 \mathrm{mg} / \mathrm{L}$, respectively. It is observed the removal of (TSS) reduces along the treatment line is comprises with the higher limit recommended by $(\boldsymbol{E C P})$ for the re-use of treated domestic waste water $(80 \mathrm{mg} / \mathrm{L})$. The high concentration of the settleable (TSS) in anaerobic ponds results a high TSS removal without generation of new algal cells. As the water moves in the pond series, the amount of the settleable suspended solids decreases. This may attributed to the low concentration of (TSS), low values of sulphide and lower surface organic loadings in the ponds.

$\boldsymbol{E C P}$ [12] defines the treatment degrees as A, B, and C. Each degree has a specific value for TSS. (ECP) defines the specific use of the treated wastewater for each group. The maximum limit of TSS for Group C is $20 \mathrm{mg} / \mathrm{L}$ which achieved by tertiary treatment plants. While the limit of TSS for Group B is $50 \mathrm{mg} / \mathrm{L}$ which fulfilled in secondary treatment. Group A limits (TSS) to $250 \mathrm{mg} / \mathrm{L}$. The concentrations of (TSS) measured over the three years are shown as in Fig. (12). The monthly average effluent (TSS) indicates the treated water from TAHTA plant belongs to the group B for some months in the years of 2015 and 2016, while for 2014 all values belongs to group B which is acceptable to irrigate wooden tree forsts.

Variations of total removal efficiency of (TSS) for TAHTA plant are calculated according Eq. (1) from the influent and effluent measured concentrations of total suspended solids (TSS) over the years of 2014, 2015 and 2016. The calculated efficiencies are shown drawn against the time (months) for the three years as in Fig. (13). It is seen the overall removal efficiency of (TSS) varied between $85.7 \%$ and $74.2 \%$ for 2014 and varied 
Gamal Abozeid, et al., Influence of inflow sewage characteristics on the performance of tahta ........

between $83.8 \%$ and $68.0 \%$ for 2015 while it is varied between $82.2 \%$ and $70.9 \%$ for 2016 . It is noted that the yearly average removal efficiency equals to $81.72 \%, 79.57 \%$ and $74.8 \%$ for 2014, 2015 and 2016, respectively. The lower efficiency is recorded at 2016. It may attributed to the incoming rate of sewage is higher than the plant design capacity and may due to sludge accumulation in anaerobic ponds. Any how the system is working well with overall removal efficiency of (TSS) higher than $44.3 \%$ that found by (Ghazy et al. 2008) [18]. Also, it is seen in February a decrease in TSS removal efficiency. This may be attributed to the wind and temperature effects in this month.

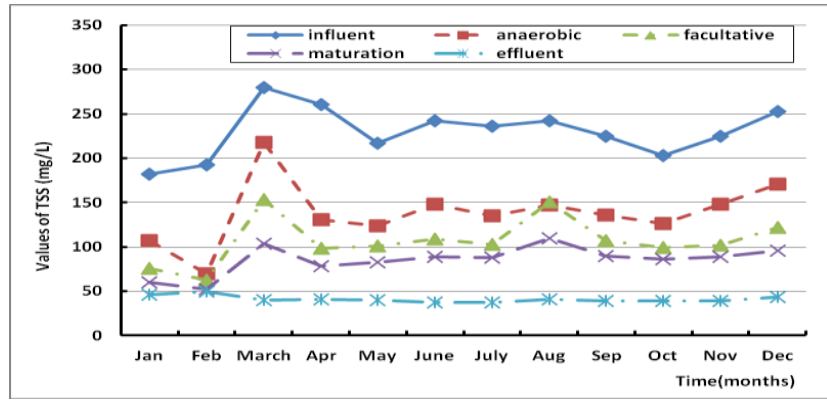

Fig 11. Variations of wastewater (TSS) along TAHTA plant series of ponds measured at the year of 2014.

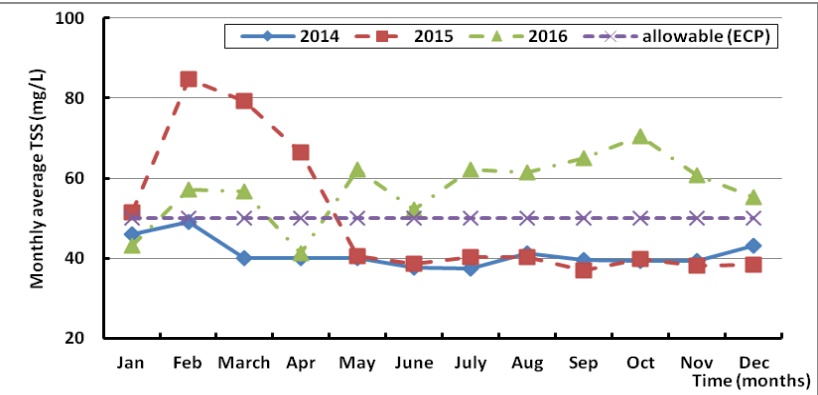

Fig. 12. Values of the measured (TSS) of the effluent and the allowable ones for TAHTA WSPs at the years 2014, 2015 and 2016.

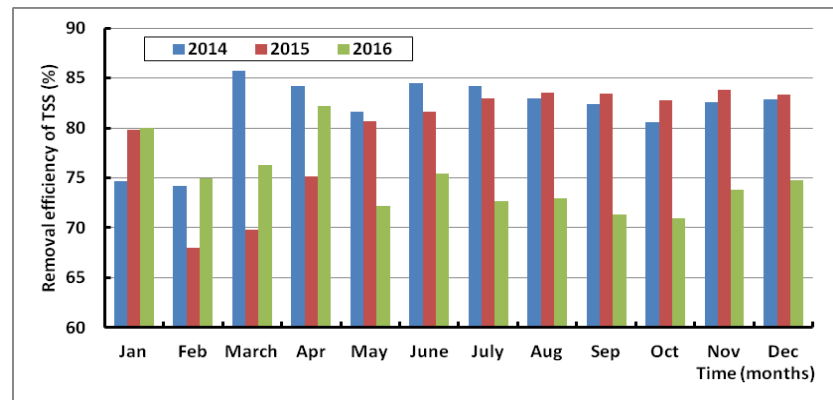

Fig 13. Variations of total removal efficiency of (TSS) for TAHTA plant over the years of 2014, 2015 and 2016.

\section{Performance of TAHTA plant in the form of (TDS) increament}

Shown in Fig (14) are the measured total dissolved solids (TDS) for the plant components at the year of 2014 as an example. The annual mean concentration in the sewage was $680.92 \mathrm{mg} / \mathrm{L}$, in the anaerobic, facultative and maturation ponds were 718.75 $\mathrm{mg} / \mathrm{L}, 733.25 \mathrm{mg} / \mathrm{L}$, and $751.7 \mathrm{mg} / \mathrm{L}$ respectively, while in the effluent it was $784.93 \mathrm{mg} / \mathrm{L}$ respectively. It was observed that TDS increases with the series of ponds. 
Figure (15) shows the drawings of monthly measured (TDS) for the three years 2014, 2015 and 2016. The effluent water from the ponds has (TDS) values that range from 700 to $900 \mathrm{mg} / \mathrm{L}$. (ECP) recommends the limit of (TDS) by a maximum value of $2000 \mathrm{mg} / \mathrm{L}$ for the use of treated water in irrigating tree forests. So, the effluent of TAHTA WSPs has (TDS) values below the recommended limits over the three years 2014, 2015 and 2016. This indicates that the effluent of TAHTA WSPs is acceptable to irrigate wooden tree forests.

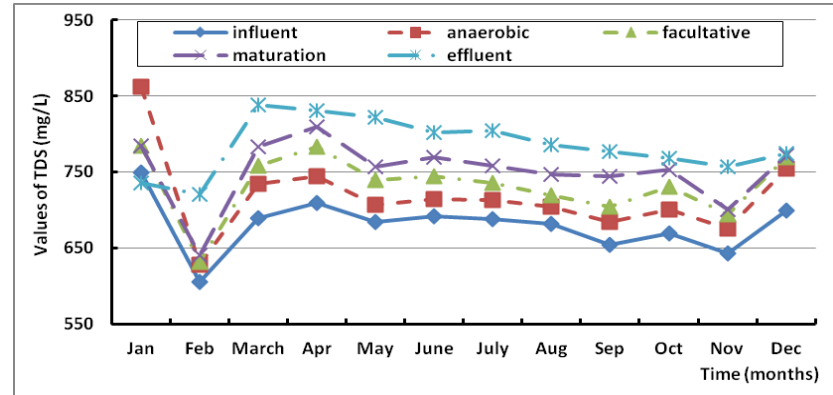

Fig 14. Variations of wastewater (TDS) along TAHTA plant series of ponds measured at the year of 2014.

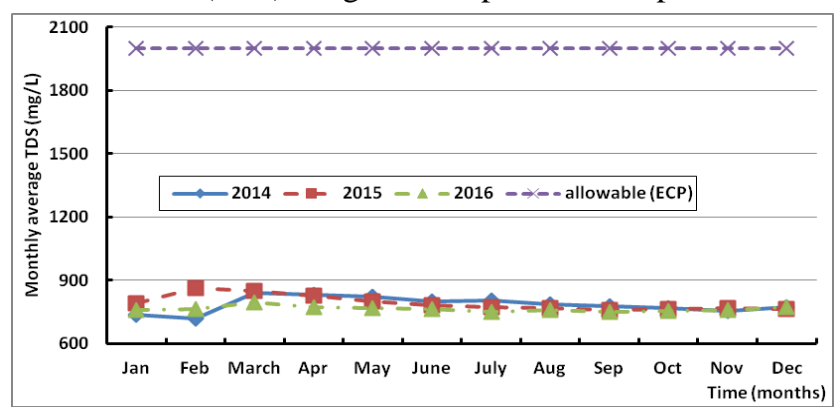

Fig. 15. Values of the measured (TDS) of the effluent and the allowable ones for TAHTA WSPs at the years 2014, 2015 and 2016.

Again from the influent and effluent measured wastewater total (TDS) over the years of 2014, 2015 and 2016, the total (TDS) increment efficiencies of TAHTA plant are calculated according Eq. (1). The calculated efficiencies are shown drawn against the time (months) of the three years as in Fig. (16). It is seen the overall increment efficiency of (TDS) varied between $19.99 \%$ and $10.71 \%$ for 2014 and varied between $26.41 \%$ and $10.79 \%$ for 2015 while it is varied between $25.41 \%$ and $7.55 \%$ for 2016 . It is noted that the annual mean increment efficiency equals to $15.78 \%, 16.91 \%$ and $14.93 \%$ for 2014,2015 and 2016, respectively. It is seen a decrease in (TDS) increment efficiency at the worm months and unclear behaviour in the cold ones. It is noticeable a low efficiency of TDS increment along the series of ponds.

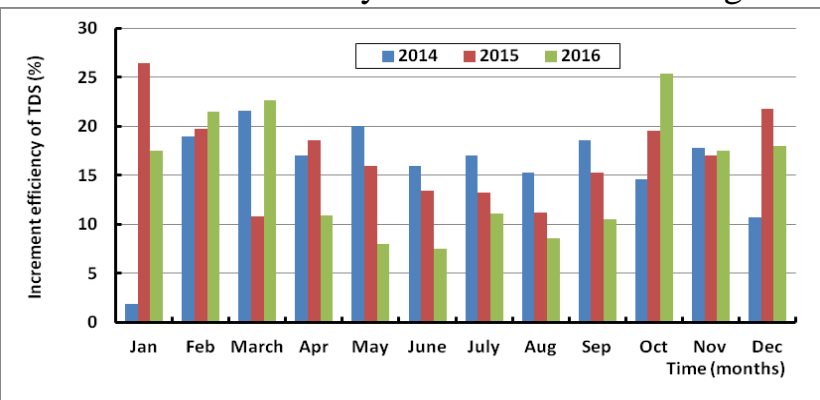

Fig 16. Variations of total increment efficiency of (TDS) for TAHTA plant over the years of 2014, 2015 and 2016. 


\section{Performance of TAHTA plant in the form of oil and grease removal}

$(\boldsymbol{E C P})$ recommends the limit of oil and grease by a maximum value of $10 \mathrm{mg} / \mathrm{L}$ for treated wastewater reuse. Figure (17) shows the drawings of the average-monthly measured effluent oil and grease and the allowable ones for TAHTA WSPs at the years of 2014, 2015 and 2016. It is seen that the best values of the effluent oil and grease are in the year of 2014. In the year of 2015, the measured oil and grease are coincide with the allowable ones except in February and March, while in 2016 the measured values are slightly higher than the allowable limit by $(\boldsymbol{E C P})$.

Variations of total removal efficiency of oil and grease for TAHTA plant over the months are calculated according Eq. (1) from the influent and effluent concentrations of total oil and grease over the years of 2014, 2015 and 2016. The calculated efficiencies are shown drawn against the time (months) of the three years as in Fig. (18). It is seen the overall removal efficiency of oil and grease is varied between $90.22 \%$ and $38.74 \%$ for 2014 and varied between $68.09 \%$ and $45.51 \%$ for 2015 while it is varied between $65.84 \%$ and $62.38 \%$ for 2016 . It is noted that the annual mean removal efficiency equals to $64.57 \%, 63.12 \%$ and $64.05 \%$ for 2014,2015 and 2016 , respectively. This is strong evidence that the system is working well. Also, it is seen all the calculated efficiencies through the months of 2015 and 2016 are located around the mean, except in February 2015 it is very low. While for 2014 , it is higher in warm months.

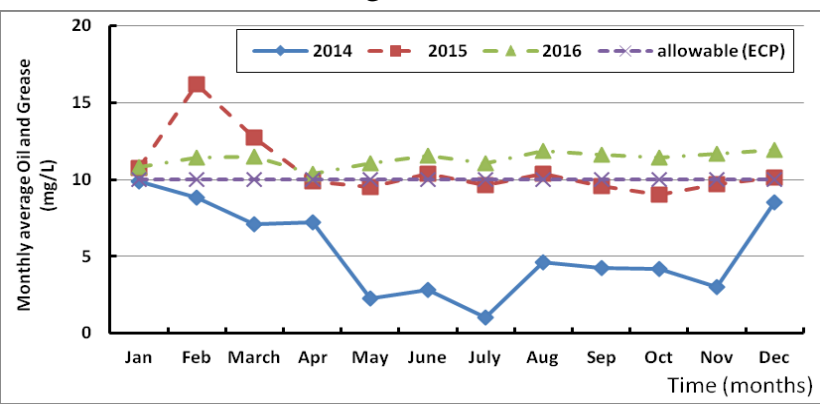

Fig. 17. Measured values of effluent Oil and Grease and the allowable ones for TAHTA WSPs at the years 2014, 2015 and 2016.

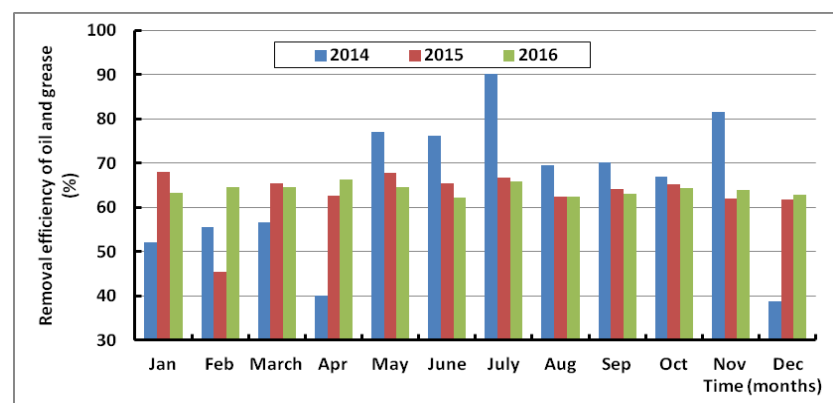

Fig 18. Variations of total removal efficiency of oil and grease for TAHTA plant over the years of 2014,2015 and 2016.

\section{Performance of TAHTA plant in the form of phosphate removal}

$(\boldsymbol{E C P})$ set the contamination level of phosphate by a maximum value of $0.5 \mathrm{mg} / \mathrm{L}$ to reuse in agriculture as $0.5 \mathrm{mg} / \mathrm{L}$. Figure (19) shows the drawings of the average-monthly measured phosphate concentration over the studied three years. The (MCL) recommended by $(\boldsymbol{E C P})$ are appeared on the figure for the purpose of comparison. The effluent of the 
WSPs has phosphate concentrations higher than the recommended one over the three years except for the period from August to December in 2014.

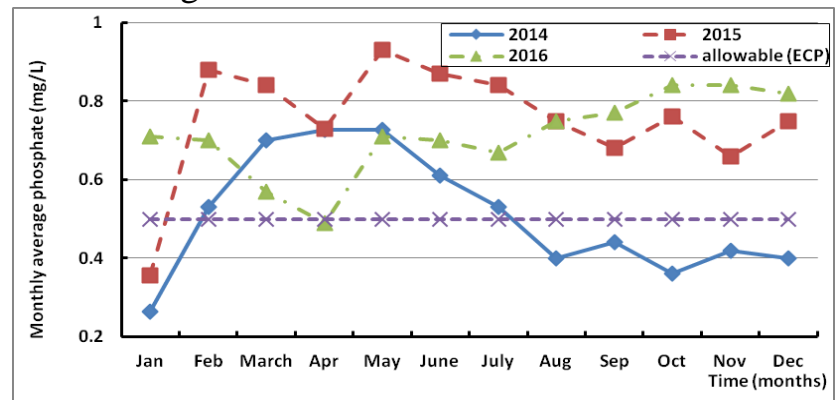

Fig. 19. Measured values of effluent phosphate and the allowable ones for TAHTA WSPs at the years 2014, 2015 and 2016.

From the influent and effluent measured total phosphate of wastewater over the years of 2014, 2015 and 2016, the monthly total removal efficiencies for TAHTA plant are calculated according Eq. (1). The calculated values of the efficiencies are shown drawn against the time (months) of the three years as in Fig. (20). It is seen the overall removal efficiency of phosphate varied between $82.27 \%$ and $52.26 \%$ for 2014 and varied between $72.95 \%$ and $31.25 \%$ for 2015 while it is varied between $60.24 \%$ and $33.33 \%$ for 2016 . It is noted that the annual mean removal efficiency equals to $67.96 \%, 42.78 \%$ and $41.7 \%$ for 2014, 2015 and 2016, respectively. Any how the system is working well.

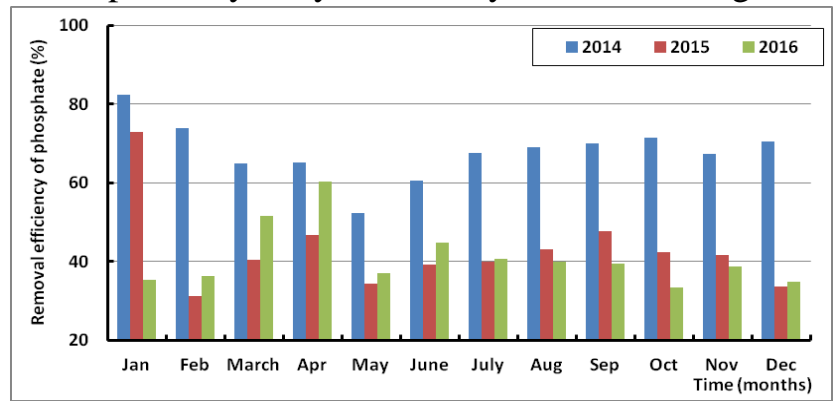

Fig 20. Variations of total removal efficiency of phosphate for TAHTA plant over the years of 2014, 2015 and 2016.

\section{Performance of TAHTA plant in the form of sulphide removal}

The drawings of the average-monthly measured sulphide concentration over the three years of 2014, 2015 and 2016 are drawn in Fig. (21). Maximum concentrations recommended by $(\boldsymbol{E C P})$ of sulphide in treated water from WSPs to be re-used in irrigating tree forests is $1.0 \mathrm{mg} / \mathrm{L}$. This value is appeared on the figure for the comparison. The effluent of the ponds has low sulphide concentrations than the recommended value over the three years except for the period from April to December in 2016. This may be attributed to the incoming flow rates are higher than the design one. 


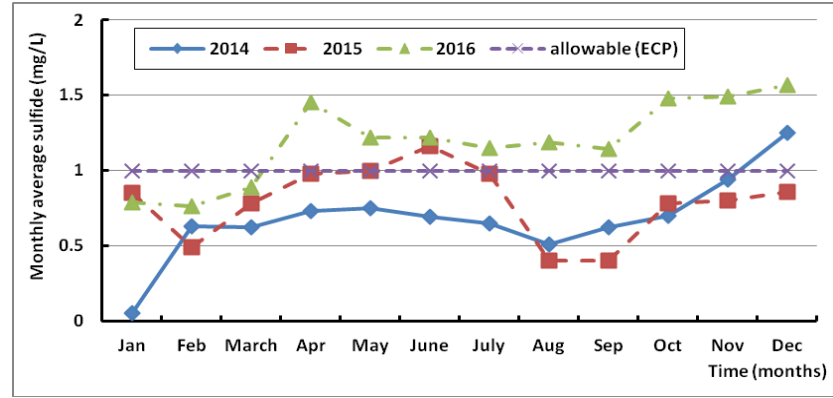

Fig. 21. Measured values of sulphide in effluent and the allowable ones for TAHTA WSPs at the years 2014, 2015 and 2016.

From the influent and effluent measured wastewater total sulphide over the years of 2014, 2015 and 2016, the monthly total removal efficiencies for TAHTA plant are calculated according Eq. (1). The calculated values of the efficiencies are shown drawn against the time (months) of the three years as in Fig. (22). It is seen the overall removal efficiency of sulphide varied between $99.52 \%$ and $83.33 \%$ for 2014 and varied between $94.44 \%$ and $84.88 \%$ for 2015 while it is varied between $89.62 \%$ and $80.90 \%$ for 2016 . It is noted that the annual mean removal efficiency equals to $90.15 \%, 89.06 \%$ and $84.92 \%$ for 2014, 2015 and 2016, respectively. This is strong evidence that the system is working well.

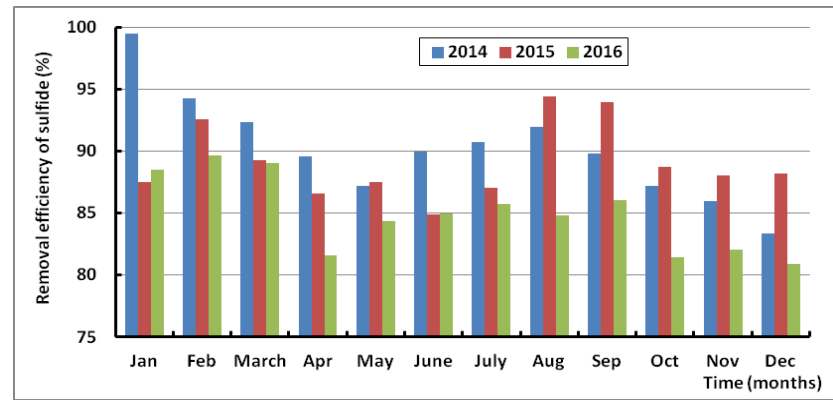

Fig 22. Variations of total removal efficiency of sulphide for TAHTA plant over the years of 2014, 2015 and 2016.

\section{Performance of TAHTA plant in the form of ammonia removal}

The monthly measured data of ammonia over the three years of 2015 and 2016 for the effluent water from the plant are drawn as in Fig. (23). Allowable value for irrigating tree forests recommended by $(\boldsymbol{E C P})$ is appeared on the figure as $10 \mathrm{mg} / \mathrm{L}$. Regardless the two high recorded values in September and December 2016, the the effluent water of WSPs has low values in comparison with the recommended ones, so it is acceptable for irrigating wooden trees.

The influent and effluent concentrations of ammonia over the years of 2014, 2015 and 2016 are measured. The monthly total removal efficiencies for TAHTA plant are calculated according Eq. (1). The calculated values of the efficiencies are shown drawn against the time (months) of the three years as in Fig. (24). 


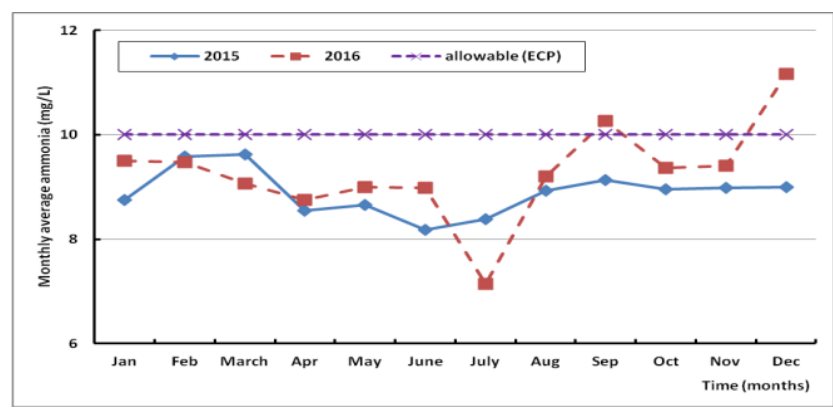

Fig. 23. Measured values of ammonia in the effluent and the allowable ones for TAHTA WSPs at the years 2014, 2015 and 2016.

It is seen the overall removal efficiency of ammonia varied between $41.9 \%$ and $16.8 \%$ for 2015 and varied between $56.32 \%$ and $33.43 \%$ for 2016 while no recorded data for 2014. It is noted that the annual mean removal efficiency equals to $31.34 \%$ and $40.27 \%$ for 2015 and 2016, respectively.

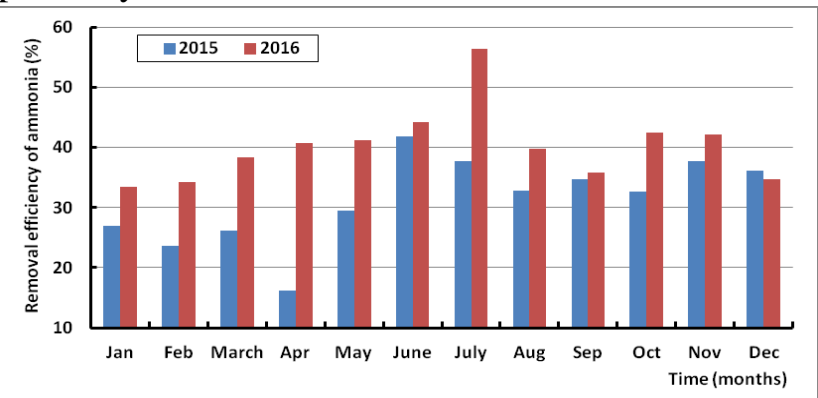

Fig 24. Variations of total removal efficiency of ammonia for TAHTA plant over the years of 2014, 2015 and 2016.

For the purpose of comparison between the measured and design (BOD5) of anaerobic pond, Fig. (25) is drawn for the measured $\left(\mathrm{BOD}_{5}\right)$ of influent $(\mathrm{Li})$ and that of effluent (Le) with the months of 2014 as an example. The design ones calculated from the following equation (Vincentetal, 1963 [19]):

$$
\left(\mathrm{BOD}_{5}\right)_{\mathrm{e}}=(\mathrm{BOD})_{\mathrm{i}} /\left[\mathrm{k} \mathrm{x} \mathrm{t}\left(\left(\mathrm{BOD}_{5}\right)_{\mathrm{e}} /\left(\mathrm{BOD}_{5}\right)_{\mathrm{i}}\right)^{4.8}+1.0\right]
$$

In which; $\left(\mathrm{BOD}_{5}\right)_{\mathrm{e}}$ is the effluent BOD $(\mathrm{mg} / \mathrm{L}),(\mathrm{BOD})_{\mathrm{i}}$ is that one of influent from anaerobic pond, $\mathrm{k}$ is constant depending on temperature and equals to 6 at $20^{\circ} \mathrm{C}$ and $\mathrm{t}$ is the retention time (days). Equation (2) is used in the design of TAHTA anaerobic pond at maximum capacity (Des Li \& Des Le) and those calculated at the existence operation parameters are also shown on the figure. It is seen that the measured $\mathrm{BOD}_{5}$ values of the influent is lower than the design ones for maximum capacity due to the low values of (Li) and low flow rates of coming sewage. While they are higher than the calculated values from the deign equation at the existing operation parameters. This may be attributed to the sludge accumulation in the pond and the existing values of sulphide. 


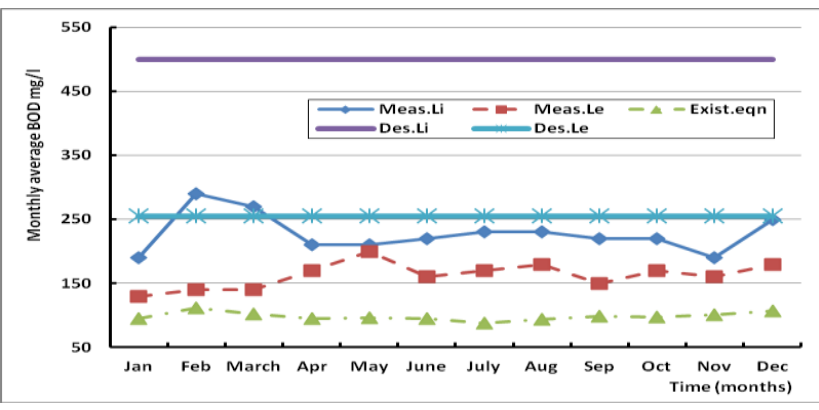

Fig. 25. Existing values of $\mathrm{BOD}_{5}$ computed from design Eqn. of TAHTA plant (Eq.2) and design values at maximum capacity in comparison with the measured values for anaerobic pond at 2014.

For facultative ponds, the measured $\left(\mathrm{BOD}_{5}\right)$ at the year of 2014 are drawn in Fig. (26) with the calculated ones from Eqn. (3) - the design equation used in TAHTA Plant (Gloyna, 1971 [20])- as:

$$
\left(\mathrm{BOD}_{5}\right) \mathrm{e}=\left[(\mathrm{BOD} 5)_{\mathrm{i}} /(\mathrm{k} \mathrm{x} \mathrm{t}+1.0)\right]
$$

Here the measured effluent $\mathrm{BOD}_{5}$ was higher than those of design ones at maximum capacity and at existing operation parameters although the influent flow rate is lower than that for maximum capacity. Also, it was higher than the mentioned by [13] between 50 and $70 \mathrm{mg} / \mathrm{L}$ as presence of the suspended algae.

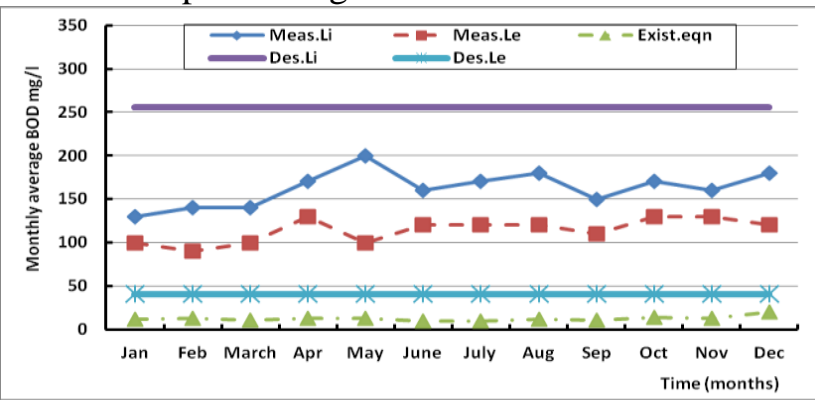

Fig. 26. Existing values of $\mathrm{BOD}_{5}$ computed from design Eqn. of TAHTA plant (Eq.3) and design values at maximum capacity in comparison with those measured for facultative pond at 2014.

\section{Conclusions}

The findings from this study may be useful in the operation and the maintenance of TAHTA plant, and when designing similar plants. The following conclusions may be drawn:

1) The plant system is working well in the period of study to fulfil the requirement of use its treated water in irrigating trees forest which is the one of its construction purposes.

2) As TAHTA WSPS performance did not meet the design one at the operation parameters such as coming discharges and $\mathrm{BOD}_{5}$ loadings for treating some parameters due to sludge accumulation in anaerobic ponds, or due to the incoming rate of sewage in 2016 is higher than the plant design capacity. So; a) Sludge accumulated in anaerobic ponds should be removed when its depth reaches $1.00 \mathrm{~m}$ according the design recommendations or when it is one half full of the sludge by volume [13]. b) Flow distribution should be checked to be uniform otherwise a short circuiting problem is faced. $c$ ) Inflow rate must be checked otherwise, to receive more of sewage inflow coming from the surround area than its design capacity some modifications may be used to improve (WSPs) efficiency. 
3) According to $(\boldsymbol{E C P})$ and $(\boldsymbol{F A} \boldsymbol{O})$ recommendation for treated wastewater re-use, the treated one from TAHTA plant can be used for irrigating wooden trees.

\section{Acknowledgement}

The authors would like to express their deep thanks to Sohage Holding Company for Potable Water and Sanitation and to technical staff in TAHTA (WSPs) plant for their support during the experimental course.

\section{REFERENCES}

[1] Tchobanoglous, G. \& Burton, F.L., "Wastewater engineering. Management", 7, 1 - 4, 1991.

[2] Kamyotra, J. \& Bhardwaj, R., "Municipal wastewater management in india", India Infrastructure Report, pp: 299-311, 2001.

[3] Mara, D., "Sewage treatment in hot climates", John Wiley \& Sons Ltd, Baffins Lane, Chichester, Sussex, 1976.

[4] Long Ho, Echelpoel, W. V., Charalambous, P., Gordillo, A.P.L., Thas, O. and Goethals, P., "Statistically-Based Comparison of the Removal Efficiencies and Resilience Capacities between Conventional and Natural Wastewater Treatment Systems: A Peak Load Scenario", Water 2018, 10, 328 (www.mdpi.com/jour./water).

[5] Von Sperling, M., "Design of facultative pond based on uncertainty analysis", Water Science and Technology, 33 (7), pp:41-47, 1996.

[6] Azab, A.," Performance evaluation of waste stabilization ponds for treatment of municipal wastewater in upper Egypt", M.Sc. Thesis submitted to Faculty of Eng. Assiut University, Egypt, 2016.

[7] Almasi, A. Mirta, M., Shokri, R., Hashemi, M., and Bahamani, N., ” Effect of solar light on the decrease of microbial contamination in facultative stabilization pond", J. Adv Environ. Health Res. Vol. 6, No. (2), pp: 90-95, 2018.

[8] Seif, D.H., Mostafa, M., Elbakri, W., and Soliman, W. r., " Study of Convert Waste Stabilization Pond Geometry to Treated Wastewater Efficiency, (El-Burullus Lake, Egypt) As a Case Study", Int. J. of Res. in science (IJRS), Vol. 4, No. (1), 2018.

[9] Kumar, S., Mal, G. and Sharma, H.R., "Waste Stabilization Ponds: A Technical Option for Liquid Waste Management in Rural Areas in Haryana under Swachh Bharat MissionGramin", Environ. and We Int. J. of Sci. \& Tech., Vol.13, pp. 177-187, India, 2018.

[10] Campos, H. and Von Sperling, M., "Estimation of domestic wastewater characteristics in a developing country based on socioeconomic variables", Water Sci. and Tech., 34 (3/4), 71-77, 1996.

[11] APHA, A., "Standard methods for the examination of water and wastewater", Edition No: 22, 2012.

[12]ECP for reuse of treated waste water for irrigating agricultural corps, No. 501- 2015.

[13]FAO."Wastewater Treatment and Reuse in Agriculture". M.B. Pescod. Irrigation and Drainage Paper No. 47. Rome, Italy, 1992.

[14]Mara, D.D. and Pearson, H.W.,"Waste Stabilization Ponds: Design Manual for Mediterranean Europe", Lagoon Technology International Ltd, Leeds, 1998.

[15] Konig, A., Pearson, H.W. and Silva, S.A., "Ammonia toxicity to algal growth in waste stabilization ponds", Water Science and Technology, 19 (12), 115-122, 1987.

[16] Mara, D.D., "Design Manual for Waste Stabilization Ponds in India", Lagoon Technology International Ltd., Leeds, England, 1997.

[17] Gad, A., M., Mohamed, A. A., and Gomma, A., "The performance of an existing system of waste stabilization ponds in upper Egypt”, First Ain Shams Univ. Int. Conf. on Envr. Eng., 2005.

[18] Ghazy, M.M.E.D., El-Senousy, W.M., Abdel-Aatty, A.M., Kamel, M., 'Performance evaluation of a waste stabilization pond in a rural area in Egypt”, Amer. J. of Envir. Scie., Vol. 4, No. (4), pp:316-325, 2008.

[19] Vincent, L. J., Algie, W. E. \& Marais, G. v. R. "A system of sanitation for low cost high density housing", In: Symposium on Hygiene and Sanitation in relation to Housing, CCTA/WHO, Niamey, 1961, London, Commission for Technical Co-operation in Africa, p. 135, 1963.

[20] Gloyna, E.F., "Waste stabilization ponds: World Health Organization Geneva", 1971. 
Gamal Abozeid, et al., Influence of inflow sewage characteristics on the performance of tahta ........

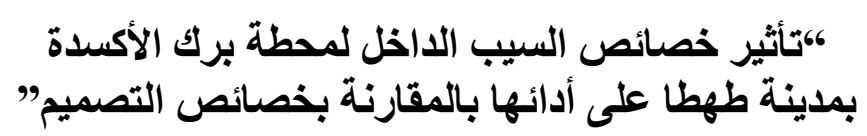

الملخص العربي

أنشأت محطة برك الأكسدة بمدينة طهطا - محافظة سو هاج بغرض معالجة ميا الصرف الصحي لهذه الهذه المدينة

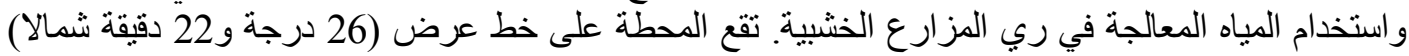

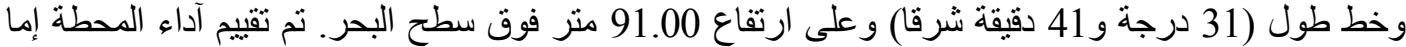

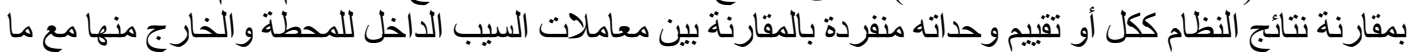

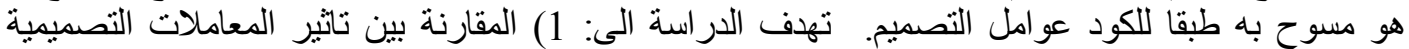

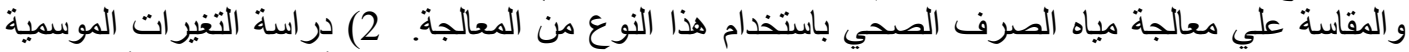

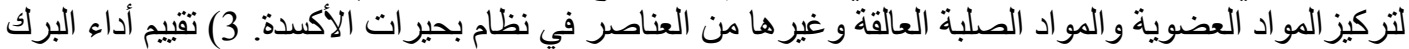

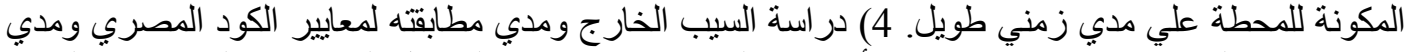

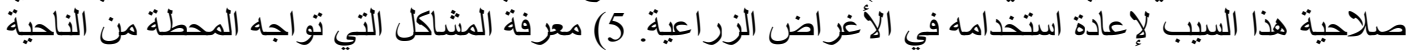

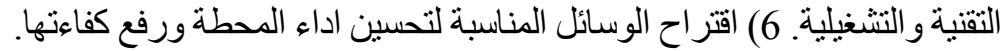

تم عمل تقييم أداء محطة بحير ات الأكسدة في مدينة طهطا بمحافظة سوهاج لمدة ثلاث سنوات ات كاملة هي

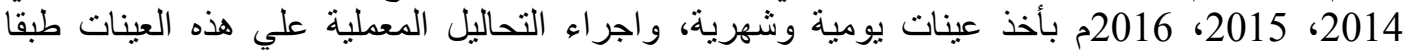

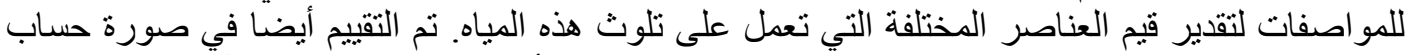

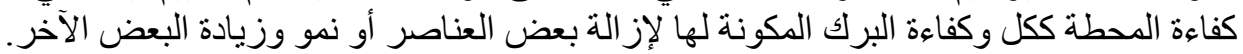

نتائج هذه الدراسة ممكن استخدامها بغرض تحسين آداء محطة طهطا أو الإستفادة منها عند تصميم محطات معالجة مماثلة و التي من أهمها:

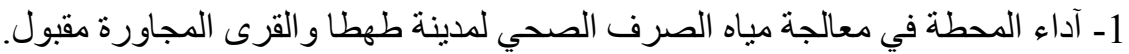

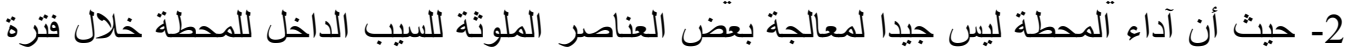

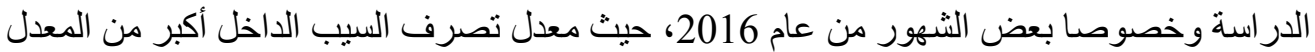

التصميمي لها، لذا بلزم بعض الإجر اءات التي من شأنها زيادة كفاءة المحطة وتحسين آدائها منها: أ) يجب إز الة الحمأة المتر اكمة بالبرك اللاهو ائية اذا ما وصل حجمه الى نصف حجم البرك طبقا لتوصيات

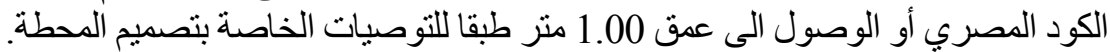

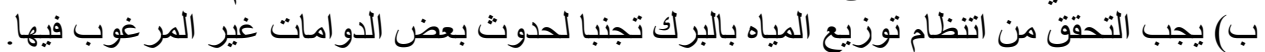

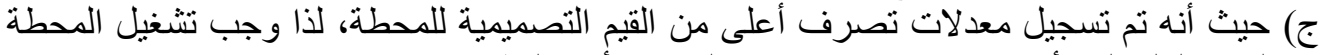
بالسعة الكلية لها أو اجر تهر دعد بلاء بعض الإضافات لتحسين أداء النظام.

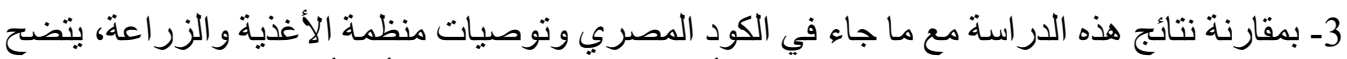

انه يمكن استخدام المياه المعالجة في زر أعة الأشجار الخشبية، وهو من أحد أغر اض اض انشاء الثة المحطة. 
JES, Assiut University, Faculty of Engineering, Vol. 47, No. 4, July 2019, pp. 475-492

List of symbols and abbreviations:

\begin{tabular}{|c|c|c|}
\hline Symbols & Definitions & Dimensions \\
\hline$A$ & Area & $\mathrm{L}^{2}$ \\
\hline $\bar{D}$ & Depth of water in pond. & $\mathrm{L}$ \\
\hline $\mathrm{H}$ & Design depth of maturation pond & $\mathrm{L}$ \\
\hline$k_{B O D_{c}}$ & Completely mixed flow first order rate constant for BOD removal & day $^{-1}$ \\
\hline$k_{F C T}$ & First order rate constant for faecal coliform removal & day $^{-1}$ \\
\hline$L$ & Latitude of the place & degrees \\
\hline$L_{e}$ & Effluent concentration of $\mathrm{BOD}_{5}$ & $\mathrm{~mL}^{-3}$ \\
\hline$L_{i}$ & Influent concentration of $\mathrm{BOD}_{5}$ & $\mathrm{~mL}^{-3}$ \\
\hline$L_{s}$ & Permissible load of $\mathrm{BOD}_{5} \mathrm{~kg} / \mathrm{ha} /$ day & $\mathrm{mL}^{-2} \mathrm{day}^{-1}$ \\
\hline$N_{e}$ & Number of effluent faecal coliform per $100 \mathrm{ml}$ & - \\
\hline$N_{i}$ & Number of influent faecal coliform per $100 \mathrm{ml}$ & - \\
\hline$n$ & Number of ponds & - \\
\hline $\mathrm{Q}$ & Mean flow rate (discharge) & $\mathrm{L}^{-3} \mathrm{day}^{-1}$ \\
\hline $\mathrm{T}$ & Temperature & ${ }^{\circ} \mathrm{C}$ or ${ }^{\circ} \mathrm{F}$ \\
\hline$t$ & Retention time & day $^{-1}$ \\
\hline$\lambda_{r}$ & Surface $\mathrm{BOD}_{5}$ removal & $\mathrm{mL}^{-2} \mathrm{day}^{-1}$ \\
\hline$\lambda_{s}$ & Surface $\mathrm{BOD}_{5}$ loading & $\mathrm{mL}^{-2}$ day $^{-1}$ \\
\hline$\lambda_{S F}$ & Surface $\mathrm{BOD}_{5}$ loading in facultative pond & $\mathrm{mL}^{-2}$ day $^{-1}$ \\
\hline$\theta^{F}$ & Mean hydraulic retention time in facultative pond & day $^{-1}$ \\
\hline$\lambda_{s m 1}$ & Surface $\mathrm{BOD}_{5}$ loading in first maturation pond & $\mathrm{mL}^{-2}$ day $^{-1}$ \\
\hline$\theta$ & Retention time & day $^{-1}$ \\
\hline$\theta_{a}$ & Hydraulic retention time in anaerobic pond & day $^{-1}$ \\
\hline$\theta_{F}$ & Hydraulic retention time in secondary facultative pond & day $^{-1}$ \\
\hline$\theta_{m}$ & Hydraulic retention time in each maturation ponds & day $^{-1}$ \\
\hline$\theta_{m}^{\min }$ & Minimum hydraulic retention time in maturation ponds & day $^{-1}$ \\
\hline Des. Le & $\mathrm{BOD}_{5}$ design concentration of effluent at maximum capacity & $\mathrm{mg} / \mathrm{L}$ \\
\hline Des. Li & $\mathrm{BOD}_{5}$ design concentration of influent at maximum capacity & $\mathrm{mg} / \mathrm{L}$ \\
\hline MCL & Maximum Concentration Level & - \\
\hline WSPs & Waste Stabilization Ponds & - \\
\hline
\end{tabular}

